УДК [37.091.12:005.963]:811.112.2

DOI: $\underline{10.35619 / \text { iiu.v2i11.209 }}$

Середюк Лариса

кандидат педагогічних наук, професор кафедри практики німецької та французької мов Рівненського державного гуманітарного університету, м. Рівне, Україна ORCID: 0000-0001-5680-564X e-mail: larisa-seredyuk@ukr.net

\title{
МІСТ МІЖ ТЕОРІЄЮ І ПРАКТИКОЮ: БЕЗПЕРЕРВНЕ ПІДВИЩЕННЯ КВАЛІФІКАЦІЇ ТА ВІДПОВІДЬ НА ВИКЛИКИ СУЧАСНОСТІ 3 КОНЦЕПЦІЕЮ «ВЧИМОСЯ НАВЧАТИ НІМЕЦЬКОЇ»
}

Анотація. Стаття присвячена дослідженню нової програми підвищення кваліфікації вчителів німецької мови Гете-інституту «Вчимося навчати німецької» на предмет ії імплементації на заняттях 3 іноземної мови. У статті проаналізовано важливість та актуальність застосування новітніх дидактико-методичних принципів, які покладені в основу програми DLL у процесі вивчення німецької мови та відповідають сучасним вимогам до знань, і за допомогою яких можна досягти високих успіхів у навчанні іноземної мови та дозволити учням діяти за допомогою мови. DLL відповідає міжнародним стандартам якості в галузі методичної освіти і пропонує завдання із систематичного спостереження та аналізу навчальної діяльності на основі відеозаписів практичних занять з іноземної мови у багатьох країнах. У програмі DLL увага зосереджується на учнях, які є головними особами в освітньому процесі. Крім того, у статті окреслено положення, що важливими залишаються і такі традиційні питання, як розвиток умінь, навчання граматиці, лексиці, фонетиці, літературі, соціальним темам роботи тощо. Усі ці аспекти інтегровані в загальну концепцію заняття, спрямованого на розвиток відповідних компетенцій учнів та студентів. Навчальні матеріали усіх модулів DLL актуалізують фахово-дидактичні знання, уможливлюють обмін досвідом та симуляцію на занятті, проводять нас заняттям від спостереження за автентичним уроком на відео до рефлексії діяльнісного підходу на уроці.

Ключові слова: DLL - програма Goethe-Institut, дидактико-методичні принципи, комунікативна компетенція, проєкт практичних досліджень, модуль.

Постановка проблеми: Україна перебуває в процесі значних змін у всіх сферах нашого життя: в політиці, економіці, суспільному житті. Ключовим чинником розвитку будь- якої країни є освіта, яка повинна не лише реагувати на зміни, але й задавати перспективи на багато років вперед, враховуючи існуючі тенденції та загрози. Від того, як будуть сформовані орієнтири в системі освіти України тепер, залежатиме майбутнє багатьох поколінь українців на наступні десятиліття. Перед освітою XXI століття стоїть глобальний виклик, - як підготувати учнів майбутнього. Актуалізація потреби у спілкуванні і співпраці між країнами, носіями різних мов, їх культурними традиціями вимагає суттєвих змін у підході до викладання іноземних мов у закладах освіти різних рівнів.

3 огляду на зміну вимог до кваліфікації вчителів і викладачів німецької мови в усьому світі німецький культурний центр Goethe-Institut в Україні при Посольстві Федеративної Республіки Німеччина в Україні розробив програму DLL - «Вчимося навчати німецької». 
Ця програма грунтується на сучасних досягненнях дидактики та методики викладання німецької мови і має на меті підвищення кваліфікації вчителів та викладачів німецької мови як іноземної.

Аналіз останніх досліджень 3 проблеми. Євроінтеграція України в Європейський освітній простір обумовлюює необхідність змін освітнього процесу як у школі, так і в закладах вищої освіти, та потребує нових підходів до викладання іноземної мови. Ці процеси зумовлюють необхідність удосконалення методики іiі вивчення. На сьогодні викладачі іноземної мови в Україні мають змогу використовувати широкий спектр методів викладання. Серед українських та зарубіжних дослідників, які досліджували питання сучасного стану викладання іноземних мов, слід виокремити праці Н. Баграмової, Р. Гришкової, І. Китайгородської, Є. Пасова, Г. Тер-Мінасової, С. Ніколаєвої та ін.

Мета статті полягає в системному аналізі нової програми підвищення кваліфікації вчителів німецької мови Гете-інституту «Вчимося навчати німецької» на предмет іiі імплементації на заняттях з іноземної мови.

Виклад основного матеріалу дослідження. DLL - програма Goethe-Institut, спрямована на підвищення кваліфікації вчителів та викладачів німецької мови. Вона грунтується на сучасних досягненнях у галузі німецької мови як іноземної та інтегрує іноваційний підхід до підвищення кваліфікації - дослідження через діяльність. DLL враховує вимоги до програм з підвищення кваліфікації вчителів та відповідає міжнародним стандартам якості у зазначеній галузі.

Метою програми є актуалізація та розширення знань, отриманих під час професійного навчання, подальший розвиток методичної компетенції та оволодіння додатковою кваліфікацією (Legutke, Michael / Rotberg, Sabine, 2018).

Цільова аудиторія. Вчителі німецької мови середніх та вищих закладів освіти з досвідом викладання німецької мови, вчителі-початківці та студенти закладів вищої освіти педагогічного спрямування. Необхідний мовний рівень, - починаючи 3 В2 відповідно до Загальноєвропейських рекомендацій з мовної освіти (Ніколаєва, 2003).

В основу програми DLL покладені такі дидактико-методичні принципи: компетентнісний підхід, міжкультурне навчання, врахування індивідуальних особливостей учнів, орієнтація на актуальний зміст, діяльнісний підхід, орієнтація на інтеракцію, автономне навчання, орієнтація на виконання практико-орієнтованих завдань, орієнтація учнів на успіх, активізація учнів (Ende, Karin, 2013).

DLL не надає переваги жодному конкретному методу навчання німецької мови. Наймовірніше, можуть бути рекомендовані дидактико-методологічні принципи, що відповідають сучасним знанням, і за допомогою яких можна досягнути високого успіху в навчанні іноземної мови та дати учням змогу діяти за допомогою мови.

Компетентнісний підхід. Усі заняття при такому підході до викладання іноземних мов спрямовані на розвиток навичок. Це передбачає, що уроки плануються з урахуванням компетенцій, які мають бути засвоєні. Очікування від ефективності уроку сформульовані у вигляді явних описів знань та вмінь. Орієнтація на компетенції також означає, що потрібно перевіряти, чи учні у кінці певного проміжку часу володіють цільовими компетенціями. Звичайно, ми не можемо перевірити всі сфери компетенції, які слід розвивати. Іншими словами, не всі цілі навчання є одночасно метою перевірки. Отже, зазвичай на уроках іноземних мов не перевіряються навички, пов'язані з особистісно орієнтованим навчанням, а ймовірніше процедурні, зокрема, розуміння слухання та читання, говоріння, письмо тощо.

Міжкультурне навчання. Лінгвістична дія завжди інтегрується в соціокультурний контекст. Тому важливо на уроках створювати такі навчальні ситуації, завдяки яким учні 
оволодіватимуть вміннями відчувати культурний характер комунікативних дій іноземною мовою. Водночас, вони здобуватимуть знання та навички спілкування, комунікативні стратегії, за допомогою яких матимуть справу 3 реальністю життя в німецькомовному середовищі та зможуть там якнайкраще зорієнтуватися.

Врахування індивідуальних особливостей учнів. Урок, орієнтований на учасників, враховує їхню індивідуальність, інтереси та потреби в навчанні мови. Крім усього іншого, це означає, що навчальні матеріали та форми роботи можуть бути пристосовані до конкретної групи учнів і що в учнів є вибір різних завдань і підходів до проведення уроку. Це має позитивно впливати на мотивацію учнів.

Діяльнісний підхід. Викладання мови на основі цього підходу готує учнів діяти мовно, а також моделювати діяльність на уроці. Комунікативна компетенція як основна мета навчання уроку фокусується на комунікативній автентичній ситуації та навчальних матеріалах, а також на прагматично відповідній мовній поведінці. Діяльнісний підхід грунтується на принципі «орієнтації на комунікацію».

Орієнтація на інтеракцію. Орієнтація на взаємодію вимагає, щоб учні це робили за допомогою завдань, які заохочують їх до співпраці один з одним. Це означає, наприклад, що вони можуть висловити власну думку та вміти реагувати на твердження інших. Завдання повинні бути розроблені у такий спосіб, щоб учні могли взаємодіяти між собою, наприклад, у формі рольової гри, через використання різних соціальних форм або через завдання, що мають на меті домовитись про щось, переконати когось або повідомити про щось, чого інша сторона ще не знає.

Автономне навчання. Учні мають відчувати постійну підтримку в їхньому свідомому бажанні до самостійності. Класні рішення та процедури повинні спрямовуватися 3 самого початку на розуміння мови та використовувати досвід вивчення мови якомога ефективніше і водночас дізнаватися більше про мову самостійно.

Оріснтація на виконання практико-оріснтованих завдань. Орієнтація на завдання тісно пов'язана з орієнтацією на дії. Учні повинні стикатися із завданнями, які, або пов'язані 3 їхнім життєвим середовищем, або майбутніми мовними діями. Вони повинні мати можливість ставити «справжні» питання і відповідати іноземною мовою.

Активізація учнів. Активізація учнів передбачає їхню активну участь на занятті в класі. Активні учні беруть участь на уроці через запитання та відповіді, активно обмінюються ідеями, відкривають для себе лінгвістичні структури самі або намагаються описати їх закономірність, беруть на себе організаційні та навчальні завдання. Учні працюють більш вмотивовано та зосереджено у відповідних контекстах завдань, розвивають підвищену обізнаність про те, що вони можуть робити та як вони вивчають мову (Ende, Karin, 2013).

Успіх заняття з іноземної мови залежить, без сумніву, від багатьох чинників: доступних навчальних матеріалів, обладнання та розміру навчальних кімнат, навчальних планів, що відіграють також велику роль в успішному проведенні заняття. Але, як показують останні дослідження, зокрема дослідження Джона Хаттьє, на першому місті в підготовці та проведенні успішного заняття $\epsilon$ іншомовна, фахово-дидактична та педагогічна компетентність вчителя. Саме це дає змогу за відповідних конкретних умов створити таке сповнене життям заняття з іноземної мови, в результаті якого ті, хто навчається, отримують можливість в багатомовних та полікультурних аспектах брати на себе відповідальність діяти за допомогою іноземної мови.

Систематичний розвиток компетенції в навчанні може вважатися як невідкладне завдання закладів освіти, і тому Goethe-Institut розробив цілу серію розділів (модулів) 3 підвищення кваліфікації DLL («Вчимося навчати німецької»). Але основною метою такого 
навчання $\epsilon$ проведення PEP (Praxiserkundungsprojekt)/ ППД (проєкт практичних досліджень). Він $є$ центральною активністю заходів 3 підвищення кваліфікації в DLL.

У програмі DLL увага зосереджується на учнях, які є головними суб'єктами освітнього процесу. Крім того, важливими залишаються і такі традиційні теми, як розвиток умінь, навчання граматиці, лексиці, фонетиці, літературі, соціальним темам роботи тощо. Усі ці аспекти інтегровані в загальну концепцію заняття, спрямованого на розвиток відповідних компетенцій школярів та студентів. DLL відповідає міжнародним стандартам якості в галузі методичної освіти і пропонує завдання із систематичного спостереження та аналізу освітньої діяльності на основі відеозаписів практичних занять з іноземної мови у різних країнах світу. Відеоматеріали слугують основою для розуміння заняття та вдосконалення власних професійних компетенцій через критичний аналіз педагогічних та дидактичних концепцій. Кожну тему завершує проєкт практичного дослідження, під час проведення якого учасник аналізує заняття в індивідуально визначеному аспекті (Legutke, Michael / Rotberg, Sabine, 2018).

Розвиток такого аспекту, створення серії модулів DLL мали науковий супровід референтів-науковців Гете-Інституту в Німеччині та інших експертів німецької мови як іноземної. Зокрема, до них відносяться: проф. д-р Ганс Барковський (університет Ф. Шиллера м. Сна), проф. д-р Рюдігер Гротян (Рурський університет м. Бохум), проф. д-р Міхаель Легутке (університет Юстуса Лібіга м. Гісен), проф. д-р Брітта Гуфайзен (Технічний університет м. Дармштадт).

Програма DLL пропонує на вибір такі базові теми підвищення кваліфікації:

Модуль 1: Навчальна компетенція та організація заняття.

Модуль 2: Як вивчати німецьку мову.

Модуль 3: Німецька як іноземна мов.

Модуль 4: Завдання, вправи, інтеракці.

Модуль 5: Навчальні матеріали та мультимедійні засоби.

Модуль 6: Навчальна програма та планування заняття.

Модуль 7: Перевірка, тестування, оцінювання.

Модуль 8: Раннє вивчення німецької мови.

Модуль 9: Змішане навчання німецької мови.

Модуль 10: Вивчення німецької з підліткам (Legutke, Michael / Rotberg, Sabine, 2018).

Крізь призму цих модулів заняття розглядається як комплексна подія, об'єктом уваги є вчителі й учні як головні актори на занятті, увага зосереджується при цьому на інтеракції в класній кімнаті, яка уможливлює діяльнісний підхід, на навчальних матеріалах і медіа, на плануванні заняття та зовнішніх його передумовах, таких, як типові навчальні програми та Загальноєвропейські рекомендації з мовної освіти (Ніколаєва С. Ю., 2003). Навчальні матеріали цих модулів актуалізують фахово-дидактичні знання, уможливлюють обмін досвідом та симуляцію на занятті, проводять нас заняттям від спостереження за автентичним уроком на відео до рефлексії діяльнісного підходу на уроці. При цьому виникають питання до проведення заняття, які потім трансформуються у ППД (проєкти практичних досліджень).

Усі модулі DLL доступні як в друкованій версії, так і на онлайн-платформі Moodle Гетеінституту. Семінари 3 підвищення кваліфікації онлайн роблять можливим інтерактивний обмін учасників з тьюторами курсів та учасників між собою. Вони проводяться у формі Präsenz, Online oder Blended Learning. Обмін думками під керівництвом тютора-наставника робить можливим гнучке навчання та взаємодію учасників один з одним. 
Проєкти практичних досліджень (ППД) сприяють рефлексивному засвоєнню матеріалу на власному досвіді та допомагають по-новому переоцінити заняття з німецької мови. Вибір назви ППД свідчить про те, що в ньому не йде мова про достатньо велике дослідження феноменів контексту заняття. Учасники семінарів надихаються тим, що питання або виклики, які постають перед ними на занятті, можуть бути вирішені самостійно або за допомогою колег. При проведенні ППД вони спостерігають за контекстом заняття, опитують учнів, опрацьовують фахово-дидактичні рішення i перевіряють це все на власному занятті. Кожен семінар з підвищення кваліфікації завершується для учасників плануванням, проведенням і презентацією проєкту практичного дослідження в тридемах або тандемах.

Є три типи питань ППД, за допомогою яких відбувається взаємодія змісту DLL-модулів і практики заняття:

1. Практичні розвідки з метою встановлення результатів за зразком: «Яким є моє заняття щодо заняття X? Як я його оцінюю з точки зору моєї повсякденної практики? Який погляд на це заняття мають мої учні?»

2. Практичні розвідки з метою змінити щось за зразком: «Якщо я один раз випробую $\mathrm{X}$, що зміниться на моєму занятті?»

3. Практичні розвідки з метою випробувати або модифікувати за зразком навчальну активність або інструмент, які запропоновані в DLL i до цього не були відомі: «Я налаштований скептично щодо того, що моя навчальна група є гомогенною в мовному плані. Я хотів би за допомогою мовного портфоліо дізнатися, чи $є$ мовне різноманіття в моїй групі?»

Для роботи з ППД запропонований такий хід подій:

1. Збір інформації для ППД під час роботи над модулем.

2. Спільне планування ППД в малих групах в кінці кожної фази.

3. Індивідуальне проведення ППД.

4. Презентація і дискусія щодо ППД в заключній фазі навчання.

У підготовці і проведенні ППД значну роль відіграють тьютори-наставники завдяки своїй опіці і порадам. Тренери мусять володіти як фундаментальними компетенціями тьютора, так і високо розвиненими здібностями й знаннями стосовно змісту і концепції DLL (Legutke, Michael / Rotberg, Sabine, 2018).

Висновки і перспективи подальших розвідок. Отже, робота за новою програмою Goethe-Institut «Вчимося навчати німецької» (DLL) передбачає розвиток таких вмінь i навичок:

- використання інформаційних технологій для вирішення професійних завдань (пошук необхідної інформації, підготовка презентацій, кліпів та ін.);

- автономне навчання та самоорганізація;

- робота в групі (планування роботи, розподіл ролей, взаємодопомога);

- уміння знаходити декілька способів рішення проблемної ситуації, вибір та обгрунтування найбільш раціонального варіанту;

- навички проведення презентацій (представлення результатів виконаного завдання), ведення дискусії тощо,

- навички роботи на онлайн-платформі Moodle Гете-Інституту.

Студенти та слухачі курсів отримують можливість розвивати мовні, комунікативні та методичні вміння, набувати досвіду роботи у віртуальному освітньому середовищі. Перспективи подальших наукових розвідок вбачаємо у систематизації й популяризації 
такого досвіду роботи у віртуальному освітньому середовищі, що є актуальним у сучасному інформаційному суспільстві.

\section{СПИСОК ВИКОРИСТАНИХ ДЖЕРЕЛ}

Ніколаєва С. (2003) Загальноєвропейські рекомендації з мовної освіти: вивчення, викладання, оцінювання. Київ: Ленвіт, 2003. 273 с.

Ende, Karin u.a. (2013) Curriculare Vorgaben und Unterrichtsplanung. Deutsch Lehren Lernen. Einheit 6. München: Langescheidt.

Legutke, Michael / Rotberg, Sabine(2018) Deutsch Lehren Lernen (DLL) - das weltweite Fortund Weiterbildungsangebot des Goethe-Instituts. In: InfoDaF. Band 45, Nr. 5, 2018, S. 605-634.

\section{REFERENCES}

Nikolaieva S. (2003) Zahalnoievropeiski rekomendatsii z movnoi osvity: vyvchennia, vykladannia,otsiniuvannia. [Pan-European Recommendations for Language Education: Study, Teaching, Assessment] . Kyiv: Lenvit, 2003. 273 s. (in Ukrainian)

Ende, Karin u.a.(2013) Curriculare Vorgaben und Unterrichtsplanung. Deutsch Lehren Lernen. Einheit 6. München: Langescheidt. (in German)

Legutke, Michael / Rotberg, Sabine(2018) Deutsch Lehren Lernen (DLL) - das weltweite Fortund Weiterbildungsangebot des Goethe-Instituts. In: InfoDaF. Band 45, Nr. 5, 2018, S. 605-634 (in German)

\section{LOFE-LONG PROFESSIONAL DEVELOPMENT AND ANSWER TO THE CHALLENGES OF MODERNITY IN THE CONTEXT OF THE CONCEPT "LEARNING TO LEARN GERMAN": THEORY AND PRACTICE}

Larysa Serediuk $\mathrm{PhD}$ in Pedagogy, Associate Professor, Professor at the Department of Practice of German and French languages,

Rivne State University for the Humanities, Rivne, Ukraine ORCID: 0000-0001-5680-564X e-mail:larisa-seredyuk@ukr.net

\footnotetext{
Abstract. The article analyzes the importance and relevance of applying of the latest didactic and methodological principles that underpin the DLL program in the process of German language learning and meet current requirements for knowledge, which can help the students to achieve great success in learning of foreign language and allow them to act with a language. DLL meets international quality standards for methodological education and offers tasks for the systematic observation and analysis of learning activities with a help of video recordings of foreign language lessons in different countries. DLL focuses on the students, who are the main actors in the learning process.

The article outlines also the relevant items and traditional topics such as skills development, teaching grammar, vocabulary, phonetics, literature, social work etc. All these aspects are integrated into the overall concept of the lesson, the aim of which is the development of the relevant competencies of the students.

The article is devoted to the study of the new training program of the German language teachers of the Goethe-Institut "Learning to Learn German" and its implementation in the foreign language
} 
classes. The article analyzes the importance and relevance of applying of the latest didactic and methodological principles that underpin the DLL program in the process of German language learning.

The article also analyzes the concept of a practical research project (PRP) that facilitates the reflective learning of material in one's own experience and helps to see the German lessons from a new point of view. The chosen title indicates that it does not refer to a sufficiently extensive study of the phenomena of the context of the lesson. Workshop participants are inspired by the fact that the issues or challenges they face in the classroom can be solved on their own or with the help of colleagues in the context of the PRP. During the PRP, they observe the context of the lesson, interview students, work out didactic decisions, and test it all at the lesson. Each alignment workshop culminates for the participants in planning, performing and presenting a practical research project in threesomes or tandems. Thus, the article explores that the work according to the new training program of the German language teachers of the Goethe-Institut "Learning to Learn German" involves developing skills such as using information technology to solve professional tasks, autonomous learning and self-organization, working in a group, finding the ways of solving the problem situation, choosing and justifying the most rational option, presentation skills, skills of working at the online platform of the Moodle of Goethe-Institut.

Keywords: DLL - Goethe-Institut program, didactic-methodological principles, communicative competence, practical research project, module.

Стаття надійшла до редакиії 05.02.2020 p. 